\title{
The importance of qualification of the human resources in tourism: a study applied to travel agents in Portugal
}

\author{
Lígia Maria Rocha Pinto Ribeiro* \\ Eduardo Cândido Cordeiro Gonçalves** \\ University Institute of Maia (Portugal) \\ Ricardo Jorge da Costa Guerra*** \\ Polytechnic Institute of Guarda (Portugal)
}

\begin{abstract}
Tourism has established itself as one of the most important and fastest growing economic sectors in the world. The success of this economic activity depends heavily on qualified human resources. In the case of travel agencies and tourism, travel agents are the pillar of all the dynamics of this subsector. In the absence of many specific studies on these professionals and their levels of qualification and job satisfaction, this article aims to define a profile of the travel agent in Portugal, by dividing it into four elements: socio-demographic, professional, economic and psychological and also to understand the influence of the level of qualification. A descriptive quantitative methodology with univariate and bivariate analysis was applied using primary data collection, based on the questionnaire survey of a significant number of travel agents operating in Portugal, representative of the national territorial density. The empirical results of this study allowed the general conclusion that the vast majority of travel agents have higher education qualifications with incidence in the area. Travel agents with more years of profession tend to earn better wages, although agents in higher age brackets show lower educational qualifications. However, it is not because travel agents have more education that they will get better pay; such as travel agents with a degree in tourism feel less satisfied with their profession, this correlates with inappropriate pay and high levels of stress.
\end{abstract}

Keywords: Tourism distribution; Travel agencies; Qualified human resources; Travel agent profile; tourism.

La importancia de la calificación de los recursos humanos en turismo: un estudio aplicado a las agencias de viajes en Portugal

Resumen: El turismo se ha consolidado como uno de los sectores económicos más importantes y de más rápido crecimiento del mundo. El éxito de esta actividad económica depende, en gran medida, de recursos humanos cualificados. En el caso de las agencias de viajes y turismo (AVT), las agencias de viajes (AV) son el pilar fundamental de toda la dinámica de este subsector. Dado que no existen muchos estudios específicos sobre estos profesionales y sus niveles de cualificación y satisfacción laboral, este artículo tiene como objetivo definir un perfil del agente de viajes en Portugal, pudiendo dividirlo en cuatro elementos: sociodemográfico, profesional, económico y psicológico, y comprender la influencia del nivel de cualificación. Se utilizó una metodología descriptiva cuantitativa con análisis univariado y bivariado, utilizando la recolección de datos primarios basada en la encuesta por cuestionario a un número significativo de agentes de viajes que trabajan en Portugal, representativo del espesor territorial nacional. Los resultados empíricos de este estudio nos permitieron concluir, en términos generales, que la gran mayoría de los agentes de viajes cuentan con títulos de educación superior con impacto en la zona. Los agentes de viajes con más años en la profesión tienden a ganar mejores salarios, aunque los agentes de grupos de mayor edad muestran una menor cualificación formativa. Sin embargo, también se concluye que las mejores cualificaciones académicas de los agentes de viajes no suponen necesariamente una mayor remuneración; del mismo modo, los agentes de viajes con el grado de turismo se sienten menos satisfechos con la profesión como consecuencia de una remuneración inadecuada y altos niveles de estrés.

Palabras Clave: Agencias de viajes y turismo; Recurso humano cualificado; Perfil de agente de viajes; Turismo; distribución turística.

* University Institute of Maia (Portugal); E-mail: ligiarib@hotmail.com

** University Institute of Maia (Portugal); E-mail: egoncalves@ismai.pt; http://orcid.org/0000-0003-0908-2623

*** Polytechnic Institute of Guarda (Portugal); E-mail: ricardoguerra@ipg.pt 


\section{Introduction}

Tourism is now a global industry and one of the main drivers of the economies of touristic destination countries (Costa, 2006). Tourism is therefore one of the sectors with the highest economic growth and a major source of employment (World Tourism Organization, 2020). According to Costa, Moura, Mira, et al. (2019), this industry depends directly on employees who must have the skills to meet the sector's needs. As such, tourism relies heavily on services and must therefore follow the trends and dynamics of the market, becoming critical of professional qualification (Salgado, Lemos \& Rosa, 2016; Marques, 2019).

Tourism in Portugal is therefore central to the country's economic dimension. According to the latest results presented by the Portuguese Goverment (Turismo de Portugal, 2020) for 2019, this sector was responsible for the country's largest economic export activity, namely "for $52.3 \%$ of services exports and $19.7 \%$ of total exports and employed 336,800 people with a weight of $6.7 \%$ in the national economy.

Human resources are considered by the World Tourism Organization (2020) as the main pillar for the proper functioning of this sector. Their academic capacity is increasingly focused on higher education in order to respond to market demands and challenges (Eurico, Silva \& Valle, 2012; Marques, 2019). In turn, higher education institutions are increasingly impelled to create programmatic contents articulated with the needs of the industry, which will allow these future professionals to better adapt to the labor market (Ribeiro, 2019; Eurico, Silva \& Valle, 2012).

In recent years, human resources are undergoing some changes due to the introduction of robotics, new technologies and artificial intelligence. These changes have led professionals to specialize and change their roles, as they have begun to perform higher value-added tasks where human skills are very difficult to automate (World Tourism Organization, 2020).

The studies carried out on this sub-sector have rarely systematically addressed the reality of travel agencies and tour operators. The aim of this study is to demonstrate the qualifications and satisfaction levels of these professionals, as well as to create a profile for the Portuguese travel agent. The study design involves (i) literature review; (ii) methodology adopted; (iii) presentation and discussion of results; (iv) conclusions and proposals for future research.

\section{Literature review}

\subsection{The importance of qualified education of human resources in tourism}

Tourism is considered to be one of the largest generators of employment due to its intensive nature, multiplier effect (World Tourism Organization, 2020) and its strong dependence on human resources (Martins \& Machado, 2002). In this industry, human resources, mainly in the most developed countries, have undergone changes in recent years due to commercial, social, legislative, ethical and technological issues (Baum, 2015). These changes are related to the creation of new business models, new consumption patterns, changes in supply and demand dynamics and in tourism distribution itself (World Tourism Organization, 2020; Baum, 2015). Table 1 shows some of the changes that have contributed to updates in the qualification of human resources, with direct implications for training and education in this area.

\section{Table 1: Factors that have affected the tourism sector and its implications}

\begin{tabular}{|l|l|l|}
\hline Factors that affected tourism sector & Authors & $\begin{array}{l}\text { Implications on the professionals of } \\
\text { the sector }\end{array}$ \\
\hline $\begin{array}{l}\text { Changes in travel patterns both in origin and } \\
\text { destination }\end{array}$ & Baum, 2015 & New skills related to digital tools \\
\hline $\begin{array}{l}\text { Consumer has become more independent and } \\
\text { started to organize his own travels }\end{array}$ & Babu, 2014 & More customized service \\
\hline $\begin{array}{l}\text { Reduction on operational costs in some tourism } \\
\text { subsectors (aviation, Hotels, etc.) }\end{array}$ & $\begin{array}{l}\text { Capa, 2013, mentioned by } \\
\text { Baum, 2015 }\end{array}$ & $\begin{array}{l}\text { Attempted elimination of intermediaries } \\
\text { (eg. TA, TO) implementing strategies to } \\
\text { maintain active in distribution }\end{array}$ \\
\hline $\begin{array}{l}\text { The impact of social media in the consumers } \\
\text { decision }\end{array}$ & $\begin{array}{l}\text { Xiang, Margini \& } \\
\text { Fesenmaier, 2015 }\end{array}$ & $\begin{array}{l}\text { Adopting new strategies of } \\
\text { communication (e.g. Social media) }\end{array}$ \\
\hline Changes in the tourism distribution system & $\begin{array}{l}\text { Mistilis, Buhalis, \& } \\
\text { Gretzel, 2014 }\end{array}$ & Create new skills and new jobs \\
\hline $\begin{array}{l}\text { Increased sensitivity towards social and } \\
\text { sustainability issues }\end{array}$ & Baum, 2015 & $\begin{array}{l}\text { Search for professionals with skills } \\
\text { related to social and sustainability issues }\end{array}$ \\
\hline
\end{tabular}

Source: Adapted from Baum (2015) 
All the above changes "oblige" human resources to be highly qualified in order to comply with these changes and market demands.

Traditionally these resources were composed of easily accessible and unskilled labor associated with emigration, sometimes illegal, which was only hired to meet excessive summer demand (Costa, 2004; Eurico, Silva \& Valle, 2012). This whole scenario led for decades to society marginalising jobs in tourism, seeing it as a job with no future due to its precariousness and low wages (Eurico, Silva \& Valle, 2012). The increase in the importance of tourism in national economies, competition and the decrease in seasonality, have led tourism companies to invest in quality and excellence services in order to differentiate themselves (Martins \& Machado, 2002). These companies, through their human resources departments, started to recruit and manage specialized professionals (Marques, 2019) and abandoned low-cost recruitment policies (Lillo-Bañuls, Sevilla, \& Ramón-Rodriguez, 2007), providing the consumer with more personalized and qualified services (Martins \& Machado, 2002). Moreover, the performance of these professionals will directly influence the level of consumer satisfaction (Lillo-Bañuls, Sevilla, \& Ramón-Rodriguez, 2007; Martins \& Machado, 2002). According to the World Tourism Organization (2020), the future of human resources depends on continuous training that goes from basic skills to the most varied techniques, allowing the creation of more consumer-oriented professionals.

In the sub-sector of travel agencies, it is crucial that their professionals have certified qualifications to be able to meet the demands of the market. From Martínez-Martínez, Cegarra-Navarro \& Wensley's (2017) perspective, travel agents are considered as the "knowledge agents" who contribute to the transformation and exchange of information between the different players. They continue to play a central role for suppliers and consumers (Mckercher, Packer, Yau, \& Lam, 2003) as they are in direct contact with customers in their decisions (Wijk, Persoon, 2006; Ibarnia, 2018). This ability gives them the "power" to guide customers by advising them in their choices through the knowledge acquired in their training and professional experience (Mckercher, Packer, Yau, \& Lam, 2003).

The qualification of human resources is a key element in the strategic document for Portuguese tourism in the light of the Tourism Strategy 2027 (Turismo de Portugal, 2017), a document formulated by Portuguese Tourism Board and the Ministry of Economy. Initially, the main players in the sector were interviewed in order to list the weaknesses and point out the guiding thread for the formulation of strategies. Four of the various weaknesses pointed out stand out as falling within the scope of this study: (i) lack of qualified human resources in tourism; (ii) improvement in the wage conditions of tourism professionals; (iii) greater coordination between educational agents in the area of tourism; (iv) training geared to the needs of tourism-related companies.

In figure 1, it is possible to observe that the Portuguese Tourism Board's forecasts for the educational qualifications of hotel, restaurant and travel agencies professionals for the year 2027 tend to double the number of professionals in secondary and higher education and to decrease those in basic education. It can also be seen that of these three sub-sectors of tourism, travel agencies are going to have more qualified professionals at higher education level, both in 2015 and 2027.

Figure 1: Educational qualification level of tourism professionals in Portugal

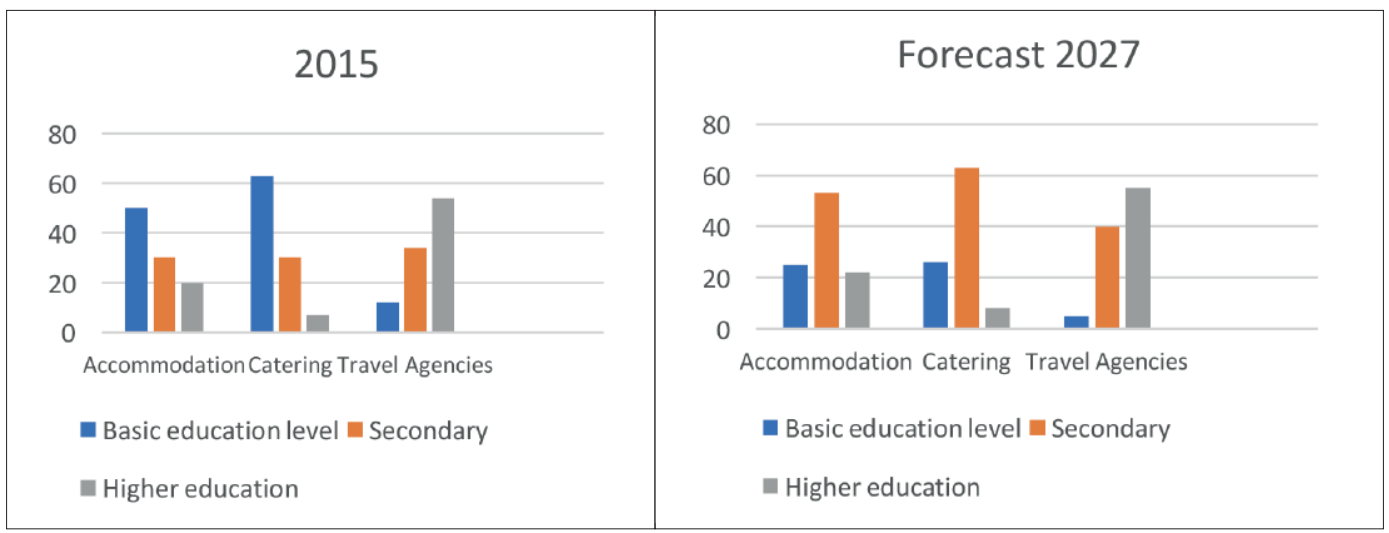

Source: Adapted from Turismo de Portugal (2017:43) 
Several strategies have also been implemented to address the weaknesses encountered. These include strategies related to human resources: (i) investment in hotel and tourism schools, reviewing curriculum plans with the aim of bringing education closer to market needs and making them specialized centers for training in tourism and entrepreneurship; (ii) creation of an education and training network in tourism; (iii) giving more prestige to tourism professionals and adapting them to market needs (Turismo de Portugal, 2017).

The Tourism Strategy 2027 aims at promoting and qualifying tourism professionals, where articulation between all stakeholders is crucial for businesses to remain competitive and respond to market needs.

\subsection{Tourism distribution, intermediaries and the travel agency sub-sector}

Tourism distribution is one of the pillars of world and national tourism. Moreover, tourism destinations would hardly survive without a distribution chain. For their existence, it must be the various stakeholders who maintain an interconnection between them, using distribution channels (Poon, 1993), according to Cooper (2001). Thus, tourism distribution must be understood of as a system, where suppliers, intermediaries and the final consumer are included. According to Poon (1993) tourism distribution is considered as one of the most important activities of the tourism system, because without the appropriate distribution chain in the market, neither the best destinations in the world would easily survive.

Kotler, Bowen et al (2003) consider the key functions performed by distribution channels in tourism, to be: i) information - grouping and distribution of marketing research and information on the market environment; ii) promotion - developing and disseminating persuasive communications for a particular promotion or supply; iii) contact - demand and communication with potential buyers; iv) negotiation - agreeing the price and other terms of supply so that the purchase can be made.

With globalization, tourism distribution has undergone several changes. The emergence of new markets, new technologies (ICT) and changes in final consumer behavior are some of the factors that have led to these unprecedented changes. Tourism distribution is currently being influenced by new trends on both the demand and supply sides (Ribeiro, 2019). Research on the subject clearly shows that distribution plays an increasingly critical role in the formulation of costs as well as differentiation strategies, affecting the added value of all components of the tourism production chain. There has been a growing desire to reduce distribution costs, forcing commission cuts, and the emergence of non-tourism organizations as intermediaries of travel products, producing major challenges for traditional operators.

For decades, travel agencies have played a central role as intermediaries in the process of tourism distribution, being considered as one of the main pillars of tourism worldwide (Vallespín \& Molinillo, 2014; Kracht \& Wang, 2009; Buhalis \& Kalis, 2008). Travel agencies have been fundamental to the entire distribution channel as they bridged the gap between suppliers and the final consumer (Viljoen $\&$ Roberts-Lombard, 2016). Intermediaries were the key to this whole process and their role was central to all transactions (Viljoen \& Roberts-Lombard, 2016; Cheung \& Lam, 2009). The consumer usually visited the travel agencies, where he collected information and purchased his travels (Cheung \& Lam, 2009).

The spread of the Internet and the development of electronic commerce have allowed consumers to use digital channels to conduct their research and make their own reservations (Cheung \& Lam, 2009; Cetin, Cifci, Dincer \& Fuchs, 2016). The emergence of direct selling websites (airlines, hotels, rent-a-car...) and search and comparison engines (Aamir \& Atsan, 2020) have given consumers the power to negotiate on their side, in particular by being able to compare prices (Sahut, 2009).

The ICT opened a window of opportunity for direct negotiation between the consumer and the various suppliers, reducing the importance of former intermediaries (Vallespín, \& Molinillo, 2014; Loaiza, Pérez-Torres \& Contreras, 2019). The basic functions of intermediation no longer make sense, as the distribution channels became shorter with the elimination of some of the central intermediaries. Travel agencies are now seen as expensive intermediaries for both suppliers and consumers (Viljoen \& Roberts-Lombard, 2016) and no longer serve their interests in part (Granados, Kauffman, Hsiangchu \& Lin, 2014).

In turn, consumers and suppliers started to negotiate directly the final prices as well as the conditions of the transactions (Belleflamme, \& Neysen, 2009). The concept of disintermediation has thus emerged, which can be observed when there is no intermediary in the touristic distribution channel (Cheung \& Lam, 2019; Buhalis \& Kalis, 2008). 
Disintermediation did not mean the end of the story for intermediaries, but the addition of new business opportunities, along with various challenges (Buhalis \& Kalis 2008) that require reorganization and reinvention in order to remain active. Faced with this new scenario, travel agencies have been "forced" to find new guiding paths, succeeding in re-establishing themselves and reaffirming their role as intermediaries, with the designation of "reintermediation" (Cheung \& Lam 2019; Kracht \& Wang, 2009). Reintermediation is the emergence of new intermediaries, between final consumers and tourism producers/suppliers, who provide touristic products and services, but within a new business model (Abranja and Magalhães, 2018).

These changes have enabled the appearance of new virtual intermediation players that have emerged quickly, such as online travel agencies (OTA) (Loaiza, Pérez-Torres \& Contreras, 2019; Cetin, et. al., 2016). Online travel agencies were created on the Internet and by the Internet, making all their traditional services available in an online environment (Pallas, 2018). This intermediary is much more powerful than its previous version (Cetin, et. al., 2016) and presents a new business model (B2C - business to customer), leaving the role of mere intermediaries and having other functionalities as business partners. They are now considered as a virtual intermediary linking the consumer to various suppliers, offering various services (Lee, Guillet \& Law, 2013; Pallas, 2018). There have been so many changes that it is possible to enunciate a before and an after of the emergence of ITCs in distribution channels.

It was at the beginning of this century that major intermediaries such as tour operators (TO), GDS (global distribution systems) and some travel agencies began to invest in e-commerce, by developing B2B2C (Business to Business to Costumer) sites. These players have boosted online travel sales to unexpected numbers (Cetin, et. al., 2016).

Nowadays virtual channels are the perfect scenario for reintermediation. They stimulate the exchange of information allowing to perceive the behavior of consumers (Loaiza, Pérez-Torres \& Contreras, 2019). For these reasons, websites, social networks and blogs became essential elements for travel agencies as they allow the creation of content that is highly valued by consumers (Pallas, 2018).

As online shopping is here to stay (Cetin, et. al., 2016), travel agencies need to gain market share by creating products or services that meet the needs of their customers (Pallas, 2018) and become relevant to them (Viljoen \& Roberts-Lombard, 2016). The ability to innovate will be the key word, by creating innovative products and services that set them apart from their competitors (Pallas, 2018; Novak,\& Schwabe, 2009). The design of new marketing and business strategies that add value both for the customer and for suppliers and partners will also be key factor of development (Kracht \& Wang 2009, Viljoen \& Roberts-Lombard, 2016). Travel agencies will thus have to be much more efficient, optimizing their human resources, creating market niches and implementing the latest ICT in their management and customization of their services (Pallas, 2018; Novak, \& Schwabe2009; Kracht \& Wang, 2009). According to Pencarelli, Bravi, Dini, \& Splendiani (2020) and Lin, 2017, travel agencies must adopt hybrid strategies that allow the combination of high-tech innovation and human interaction (the junction of the offline world with online).

\subsection{Framework for the travel agents and tourism sub-sector in Portugal}

The first travel agency to open its doors in Portugal was the Abreu Agency, which took place in 1840. It was on the initiative of Bernardo Luís Vieira de Abreu that the first travel agency was born, located in the city of Porto, in the Loureiro Street. At that time, sales were mainly made of passports, emigration visas, train and boat tickets for emigrants leaving the north of the country and Galicia for Brazil (Sousa $\&$ Pereira, 2015). Over the years, the sale of other destinations increased, as did the emergence of other competing companies. It was at the beginning of the 21 st century that major groups appeared such as Star Viagens e Turismo, Top Atlântico and Bestravel (Ribeiro, 2019).

The travel agencies in Portugal are under the guardianship of the Tourism of Portugal Board and it is through the Law-Decree no. 17/2018 of $8^{\text {th }}$ March, that states that this activity is subject to this legal framework. The sub-sector of travel agencies in Portugal consists mainly of small and medium enterprises and according to the study conducted by the Portuguese Association of Travel Agencies and Tourism (APAVT), in the year 2016, 2033 companies were identified, with a turnover in excess of 2.131 million euros, employing in total about 9687 workers. This sub-sector contributed to the national economy with 241 million euros in GVA (gross value added), of which 183 million euros are related to workers, with an average productivity of 25,000 euros per capita (Associação Portuguesa de Agências de Viagens e Turismo, 2018). 
Travel agencies in Portugal may be part of agency networks, which according to Ribeiro (2019) are divided into two groups: (i) management group of associated independent agencies; (ii) and group of agencies of the same owner. The first, are autonomous organizations, made up of independent travel agencies, with the aim of promoting them, representing them, assisting them in more technical situations and improving contractual conditions with the various suppliers. The second, according to Silva (2009:69) "are the consequence of the need for geographical expansion of travel agencies and control of operations". However, there are still travel agencies that are not part of any network.

Table 2 shows the main networks operating in Portugal. The GEA management group with 394 associated travel agencies stands out, followed by Airmet with 235 associated travel agencies and Abreu Agency with 150 shops (Ribeiro, 2019; Silva, 2017).

\section{Table 2: Main networks of travel agencies operating in Portugal}

\begin{tabular}{|c|c|}
\hline $\begin{array}{c}\text { Name of the group of travel } \\
\text { agencies }\end{array}$ & Total of TA \\
\hline Abreu & 150 \\
\hline Airmet & 235 \\
\hline Bestravel & 51 \\
\hline B The Travel Brand (Old Halcon) & 52 \\
\hline Dit Portugal & 70 \\
\hline El Corte Inglês & 20 \\
\hline GEA & 394 \\
\hline Geostar & 20 \\
\hline Go4travel & 92 \\
\hline Mercado das Viagens & 22 \\
\hline RAVT & 43 \\
\hline Top Atlântico & 60 \\
\hline Tui & 7 \\
\hline
\end{tabular}

Source: Adapted from (Ribeiro, 2019; Silva, 2017; Bestravel, 2020; B The Travel Brand, 2020; Mercado das Viagens, 2020; Viagens el Corte Inglês, 2020; Geostar, 2020; Top Atlântico, 2020)

\subsection{Higher education in tourism and tourism distribution}

Higher education is one of the vehicles for the qualification of professionals in this sector and it is divided into three study cycles: Bachelor's, Master's and Doctorate Degrees (DGES, 2019). These cycles aim to prepare future professionals to join the public or private sectors of this industry, adding value to the entities where they will work (Forte, 2017; Eurico, Silva \& Valle, 2012). The diversity of tourism activity has led to the emergence of a very complex labor market, which forces professionals in this area to obtain very distinct professional skills and very specific training needs (Eurico, Silva \& Valle, 2012).

In Portugal the higher education system is divided into sub-sectors: (1) public (public universities, public polytechnic institutes, academies, police and military institutes and schools); (2) private and cooperative (private and cooperative universities and polytechnic institutes); (3) concordat (Universidade Católica Portuguesa) (DGES, 2019).

Higher education courses are composed of curricular plans that have aggregated curricular units (CUs) that are core subjects in certain areas of study. In the tourism degree courses there are curricular units that are directly related to this subsector. A survey of all higher education tourism courses (CTESP and degree courses) that were in active during the school year 2018/2019, totaling 87 courses (41 CTESP and 46 degree courses), was carried out in order to verify the existence or not of a CU related to travel agencies. 
Table 3: Survey of CTESP courses in tourism in university level with CUs related to the travel agencies sector

\begin{tabular}{|c|c|c|}
\hline $\begin{array}{c}\text { Type of university level } \\
\text { teaching establishment }\end{array}$ & $\begin{array}{c}\text { Nr. of courses with CUs } \\
\text { related to the travel } \\
\text { agencies sector }\end{array}$ & Districts \\
\hline Public Polytechnic & 4 & Aveiro; Bragança; Portalegre; Setúbal \\
\hline Private Polytechnic & 9 & Leiria; Lisboa; Porto; Santarém \\
\hline \multicolumn{2}{|c|}{ Total of 13 CTESP } \\
\hline
\end{tabular}

Source: Elaborated from DGES (2019)

Table 4: Lists of university level courses in tourism with CUs related with the travel agencies sector

\begin{tabular}{|c|c|c|}
\hline $\begin{array}{c}\text { Type of university level } \\
\text { teaching establishment }\end{array}$ & $\begin{array}{c}\text { Nr. of courses with UCs } \\
\text { related to the travel } \\
\text { agencies sector }\end{array}$ & Districts \\
\hline Public University & 3 & Aveiro; Évora; Região Autónoma dos Açores \\
\hline Private University & 7 & Lisboa; Porto \\
\hline Public Polytechnic & 14 & $\begin{array}{c}\text { Braga; Bragança; Castelo Branco; Coimbra; } \\
\text { Faro; Guarda; Leiria; Lisboa; Porto; } \\
\text { Santarém; Viana do Castelo; Viseu }\end{array}$ \\
\hline Private Polytechnic & 8 & Lisboa; Porto; Santarém \\
\hline \multicolumn{2}{|c|}{ Total of 32 courses } \\
\hline
\end{tabular}

Source: Elaborated from DGES (2019)

Tables 3 and 4 present the CTESPs and degrees divided into public and private universities education and public and private polytechnics education. There is a greater preponderance of tourism courses in the coastal districts, as is the case of Lisbon and Porto, and a small expression in the inland districts, as is the case of Bragança, Évora and Portalegre. More courses with CUs related to travel agencies are concentrated in undergraduate courses, with a total of 32 undergraduate courses (corresponding to $70 \%$ ) and fewer in CTESP with a total of 13 courses (corresponding to $30 \%$ ).

\section{Analysis of Travel Agents in Portugal}

\subsection{Methodology}

To achieve the objective of this study, Portuguese travel agents were chosen to be inquired. Since it was impossible to include all agents, only those working with Galileo Global Distribution System (GDS) were chosen. A descriptive quantitative methodology was adopted through a questionnaire survey of 512 Portuguese travel agents. The questionnaires were distributed in two forms: paper and online. Initially they were distributed in the GDS - Galileo face-to-face trainings that are exclusive to $\mathrm{AV}$, during the months of October to December 2018. However, due to the impossibility of delivering the questionnaires to a larger pool of agents, it was decided to apply them to the private Facebook group entitled "Portuguese travel agents - professionals only", during the months of December 2018 to February 2019.

To validate the questionnaires, a pre-test was carried out with 15 agents in order to find out whether the questions were clear and easy to interpret. Once all the questions had been answered and the respondents did not experience any difficulty in understanding them, it was validated. All agents surveyed participated in this study on a voluntary basis, without any kind of outside interference. The data collected was statistically analyzed using the Statistical Package for Social Sciences (SPSS) software version 26. Descriptive and univariate analyses were performed using relative and absolute 
frequencies to characterize the sample. With the extracted results, four types of profiles were outlined: sociodemographical, economical, professional and psychological. Bivariate analyses were also performed using the Spearman correlation test to find correlations between some variables. The education level variable was identified as the independent variable.

\subsection{Data analysis}

In the analysis of the sample under study, some differentiating factors were selected which allowed the creation of four profiles: sociodemographical, professional, economical and psychological. These profiles will make it possible to introduce the Portuguese travel agent. Correlation analysis between some variables were also carried out and it is interesting to understand the relationship between the level of qualification of respondents and other factors.

\subsubsection{Results}

\subsubsection{Sociodemographical Profile}

The sample is composed mostly by female respondents (82.4\%) rather than male respondents (17.6\%), which varies widely in relation to age (Table 5). The ages most represented in the sample are agents from 31 to 40 years $(34.8 \%)$, from 21 to 30 years (29.1\%) and from 41 to 50 years $(25.6 \%)$, accounting for $89.5 \%$ of the respondents. In relation to the education level, the majority of the respondents have higher education qualifications totaling $66.3 \%$ and are specialized in tourism $62.30 \%$. The highest number of qualifications are degrees in Tourism (36.1\%), secondary education (20.9\%) and secondary education in Tourism (13.7\%).

Table 5: Sociodemographical profile of travel agents

\begin{tabular}{|l|c|c|l|c|c|}
\hline Gender & $(\mathbf{N})$ & $\mathbf{( \% )}$ & Education level & (N) & (\%) \\
Male & 90 & 17,6 & Basic Level & 5 & 1,0 \\
Female & 422 & 82,4 & High school (other) & 107 & 20,9 \\
& & & High school in Tourism & 70 & 13,7 \\
& & & Bachelor degree (other) & 6 & 1,2 \\
& & & Bachelor degree in Tourism & 43 & 8,4 \\
Age & & & Graduation (other) & 60 & 11,7 \\
18 to 20 years & 11 & 2,1 & Graduation in Tourism & 185 & 36,1 \\
21 to 30 years & 149 & 29,1 & Postgraduate studies (other) & 5 & 1,0 \\
31 to 40 years & 178 & 34,8 & Postgraduate studies in Tourism & 8 & 1,8 \\
41 to 50 years & 131 & 25,6 & Master (other) & 10 & 2,0 \\
51 to 60 years & 41 & 8,0 & Master in Tourism & 12 & 2,3 \\
More than 60 years & 2 & 0,4 & PhD (other) & 0 & 0 \\
& & & PhD in Tourism & 1 & 0,2 \\
\hline
\end{tabular}

Source: Elaborated based on performed questionnaires to the travel agents

\subsubsection{Professional Profile}

There is no great discrepancy between the various years of profession in this sub-sector, which allows to have a rather homogeneous group (Table 6). It is the agents group with 1 to 5 years of experience who are mostly represented in this sample (26.6\%). In the sample, agents with less than one year's experience are the least significant group with $9.8 \%$. The vast majority of agents work in companies that have only up to four branches, totaling $72.8 \%$ of the responses. Of the agents surveyed, $24.6 \%$ work in a travel agency that is part of the independent travel agent management group GEA. These are the group with the highest representative value in the sample and also in the Portuguese travel agency market. The remaining respondents are divided among the different networks, however, the high number of travel agencies that are not part of any network, stands out from these results. 
Table 6: Professional profile of travel agents

\begin{tabular}{|l|c|c|l|c|c|}
\hline Time working as an agent & $\mathbf{( N )}$ & $\mathbf{( \% )}$ & Agencies by network & (N) & $\mathbf{( \% )}$ \\
Less than 1 year & 50 & 9,8 & Abreu & 49 & 9.6 \\
from 1 a 5 years & 136 & 26,6 & Airmet & 54 & 10.5 \\
from 6 10 years & 67 & 13,1 & Bestravel & 14 & 2.7 \\
from 11 a 15 years & 93 & 18,2 & Gea & 126 & 24.6 \\
from 16 a 20 years & 82 & 16,0 & Geostar & 36 & 7 \\
More than 20 years & 84 & 16,4 & Go4travel & 68 & 13.3 \\
\hline $\mathbf{N}^{\mathbf{0}}$ of branches AVT & & & RAVT & 23 & 4.5 \\
1 branch & 187 & 36,5 & Top Atlántico & 8 & 1.6 \\
2 to 4 branches & 186 & 36,3 & Other & 62 & 14.1 \\
5 to 9 branches & 36 & 7,0 & None & & 12.1 \\
More than 10 branches & 107 & 20,2 & & & \\
\hline
\end{tabular}

Source: Elaborated based on performed questionnaires to the travel agents

\subsubsection{Economical Profile}

In the sample, agent's monthly income varies up to $630 €$ for part-time workers and from $631 €$ (national minimum wage) to over $2000 €$ for full-time workers. However, the vast majority of the respondents collects between $501 €$ and $1000 €$, totaling $73.2 \%$. Regarding the type of contract, $67.8 \%$ of the respondents are permanently employed in the company and only $32.2 \%$ are on a fixed-term or uncertain contract, professional traineeship or other freelance basis.

\section{Table 7: Economical profile of travel agents}

\begin{tabular}{|l|c|c|l|c|c|}
\hline Income & $\mathbf{( N )}$ & $\mathbf{( \% )}$ & Type of work contract & $\mathbf{( N )}$ & $\mathbf{( \% )}$ \\
Up to $500 €$ & 8 & 1,6 & Permanent & 346 & 67,8 \\
501 to $1000 €$ & 375 & 73,2 & Short term contract & 90 & 17,6 \\
1001 to $1500 €$ & 101 & 19,7 & Undisclosed term contract & 23 & 4,3 \\
1501 to $2000 €$ & 18 & 3,5 & Traineeship & 24 & 4,6 \\
More than $2000 €$ & 10 & 2,0 & Other & 29 & 5,7 \\
\hline
\end{tabular}

Source: Elaborated based on performed questionnaires to the travel agents

\subsubsection{Psychological Profile}

The majority of this sample (94.9\%) is satisfied, very satisfied or totally satisfied with their profession. However, when asked if they wanted to leave the profession, $33.2 \%$ replied affirmatively, and that they wanted to do so between 1 and 3 years $44.4 \%$, 4 and 6 years $21.1 \%$ and in less than one year $19.3 \%$. When asked what were the main reasons to want to leave this profession, three stood out: low salary (27.5\%), high levels of stress (26.9\%) and wear and tear in the profession (16.4\%). 
Table 8: Psychological profile of travel agents

\begin{tabular}{|l|c|c|l|c|c|}
\hline Satisfaction towards the & $\mathbf{( N )}$ & $\mathbf{( \% )}$ & Motives to want to leave this & (N) & (\%) \\
profession & 8 & 1,6 & profession & & \\
Not really satisfied & 18 & 3,5 & Wear in the profession & 28 & 16,4 \\
Not satisfied & 124 & 24,2 & Lack of consideration for the & 15 & 8,8 \\
Satisfied & 253 & 49,4 & profession & 10 & 5,8 \\
Very satisfied & 109 & 21,3 & The clients - difficulties & 13 & 7,6 \\
Totally satisfied & & & Lack of personal time for family & 46 & 26,9 \\
Considers leaving this profession & & & High levels of stress & 47 & 27,5 \\
Yes & 170 & 33,2 & Low salary & 1 & 0,2 \\
No & 342 & 66,8 & Lack of training & 11 & 2,1 \\
Intention to leave this profession & & & Others & & \\
(when) & & & & & \\
Less than 1 years & 33 & 19,3 & & & \\
from 1 to 3 years & 76 & 44,4 & & \\
from 4 to 6 years & 36 & 21,1 & & \\
from 7 to 10 years & 15 & 8,8 & & \\
More than 10 years & 11 & 2,1 & & \\
\hline
\end{tabular}

Source: Elaborated based on performed questionnaires to the travel agents

By crossing the independent variable (educational level) with the income variable, it was also possible to conclude that the majority of travel agents (73\%), receive between 501 euros and 1000 euros (table 9) and it is those with educational qualifications at the tourism degree level who are most represented (39\%). This means it is a sub-sector with a low wage index. It also turns out that the fact that travel agents have more educational qualifications does not necessarily mean a higher income. In higher incomes, between 1001 and over 2000 euros, it is the less educated travel agents who stand out, which could mean that they are the managers or managing partners of these companies who are represented here.

Table 9: Overlapped data of educational level and income

\begin{tabular}{|c|c|c|c|c|c|c|}
\hline Education level & $\begin{array}{l}\text { Up to } \\
500 €\end{array}$ & $\begin{array}{c}501 € \text { to } \\
1000 €\end{array}$ & $\begin{array}{c}1001 € \text { to } \\
1500 €\end{array}$ & $\begin{array}{c}1501 € \text { to } \\
2000 €\end{array}$ & $\begin{array}{c}+ \text { de } \\
2000 €\end{array}$ & Total \\
\hline Basic level & 0 & 3 & 2 & 0 & 0 & 5 \\
\hline High school (other) & 1 & 73 & 25 & 3 & 5 & 107 \\
\hline High school in Tourism & 0 & 50 & 18 & 2 & 0 & 70 \\
\hline Bachelor degree (other) & 0 & 4 & 1 & 1 & 0 & 6 \\
\hline Bachelor degree in tourism & 0 & 23 & 13 & 5 & 2 & 43 \\
\hline Graduate (other) & 3 & 48 & 7 & 1 & 1 & 60 \\
\hline Graduate in Tourism & 3 & 148 & 27 & 5 & 2 & 185 \\
\hline Postgraduate (other) & 0 & 5 & 0 & 0 & 0 & 5 \\
\hline Postgraduate in Tourism & 0 & 5 & 3 & 0 & 0 & 8 \\
\hline Master (other) & 0 & 7 & 3 & 0 & 0 & 10 \\
\hline Master in Tourism & 1 & 9 & 2 & 0 & 0 & 12 \\
\hline PhD (other) & 0 & 0 & 0 & 0 & 0 & $\mathbf{0}$ \\
\hline $\mathrm{PhD}$ in Tourism & 0 & 0 & 0 & 1 & 0 & 1 \\
\hline Total & 8 & 375 & 101 & 18 & 10 & 512 \\
\hline
\end{tabular}

Source: Elaborated based on performed questionnaires to the travel agents

The independent variable was also cross-checked with the degree of satisfaction (Table 10). This table allows us to conclude that it is the travel agent with a degree in tourism who feel less satisfied with their profession. This result will later be corroborated with the results of the motivations. However, the less educated travel agents are the ones who feel the most satisfied. 
Table 10: Overlapped data of educational level and satisfaction with profession

\begin{tabular}{|l|c|c|c|c|c|c|}
\hline Education level & $\begin{array}{c}\text { Really } \\
\text { not } \\
\text { Satisfied }\end{array}$ & $\begin{array}{c}\text { Not } \\
\text { Satisfied }\end{array}$ & Satisfied & $\begin{array}{c}\text { Very } \\
\text { Satisfied }\end{array}$ & $\begin{array}{c}\text { Totally } \\
\text { Satisfied }\end{array}$ & Total \\
\hline Basic level & 0 & 0 & 1 & 4 & 0 & $\mathbf{5}$ \\
\hline High school (other) & 1 & 3 & 22 & 46 & 35 & $\mathbf{1 0 7}$ \\
\hline High school in Tourism & 0 & 4 & 17 & 37 & 12 & $\mathbf{7 0}$ \\
\hline Bachelor degree (other) & 0 & 1 & 1 & 3 & 1 & $\mathbf{6}$ \\
\hline Bachelor degree in tourism & 0 & 1 & 10 & 21 & 11 & $\mathbf{4 3}$ \\
\hline Graduate (other) & 0 & 1 & 15 & 34 & 10 & $\mathbf{6 0}$ \\
\hline Graduate in Tourism & 7 & 7 & 49 & 93 & 29 & $\mathbf{1 8 5}$ \\
\hline Postgraduate (other) & 0 & 0 & 0 & 3 & 2 & $\mathbf{5}$ \\
\hline Postgraduate in Tourism & 0 & 0 & 1 & 2 & 5 & $\mathbf{8}$ \\
\hline Master (other) & 0 & 0 & 6 & 3 & 1 & $\mathbf{1 0}$ \\
\hline Master in Tourism & 0 & 1 & 2 & 7 & 2 & $\mathbf{1 2}$ \\
\hline PhD (other) & 0 & 0 & 0 & 0 & 0 & $\mathbf{0}$ \\
\hline PhD in Tourism & 0 & 0 & 0 & 0 & 1 & $\mathbf{1}$ \\
\hline Total & 8 & $\mathbf{1 8}$ & $\mathbf{1 2 4}$ & $\mathbf{2 5 3}$ & $\mathbf{1 0 9}$ & $\mathbf{5 1 2}$ \\
\hline
\end{tabular}

Source: Elaborated based on performed questionnaires to the travel agents

When we cross the independent variable and the variable "intends to leave the profession" (table 11), it can be observed that it is the travel agent with high school education qualifications up to the tourism degree who consider leaving the profession representing $92 \%$ of the answers. However, the vast majority of travel agents who consider leaving the profession have a degree in tourism (44\%). These figures may be related to the high number of respondents with these qualifications.

Table 11: Overlapped data of educational level with intending to leave this profession

\begin{tabular}{|l|c|c|c|}
\hline Education level & Yes & No & Total \\
\hline Basic level & 2 & 3 & $\mathbf{5}$ \\
\hline High school (other) & 19 & 88 & $\mathbf{1 0 7}$ \\
\hline High school in Tourism & 27 & 43 & $\mathbf{7 0}$ \\
\hline Bachelor degree (other) & 2 & 4 & $\mathbf{6}$ \\
\hline Bachelor degree in tourism & 13 & 30 & $\mathbf{4 3}$ \\
\hline Graduate (other) & 21 & 39 & $\mathbf{6 0}$ \\
\hline Graduate in Tourism & 74 & 111 & $\mathbf{1 8 5}$ \\
\hline Postgraduate (other) & 1 & 4 & $\mathbf{5}$ \\
\hline Postgraduate in Tourism & 2 & 6 & $\mathbf{8}$ \\
\hline Master (other) & 5 & 5 & $\mathbf{1 0}$ \\
\hline Master in Tourism & 4 & 8 & $\mathbf{1 2}$ \\
\hline PhD (other) & 0 & 0 & $\mathbf{0}$ \\
\hline PhD in Tourism & 0 & 1 & $\mathbf{1}$ \\
\hline Total & $\mathbf{1 7 0}$ & $\mathbf{3 4 2}$ & $\mathbf{5 1 2}$ \\
\hline
\end{tabular}

Source: Elaborated based on performed questionnaires to the travel agents 
With the crossing of educational qualifications and the reasons for leaving this profession (Table 12), we can conclude that travel agents with a degree in tourism highlight, as the main reason, the high levels of stress and low salary (corresponding to 25\%). The high levels of stress may be related to the fact that the travel agent sells a service, but is not able to control all the stages of this process, as it depends on the service of third parties (other suppliers).

Table 12: Overlapped data of educational level and motives for leaving the profession

\begin{tabular}{|c|c|c|c|c|c|c|c|c|}
\hline Education level & $\begin{array}{l}\text { Wear } \\
\text { and } \\
\text { tear }\end{array}$ & $\begin{array}{c}\text { Lack of } \\
\text { consideration }\end{array}$ & Clients & $\begin{array}{c}\text { Lack of } \\
\text { personal } \\
\text { time }\end{array}$ & $\begin{array}{l}\text { High } \\
\text { levels } \\
\text { of } \\
\text { stress }\end{array}$ & $\begin{array}{c}\text { Low } \\
\text { salary }\end{array}$ & Others & Total \\
\hline Basic level & 1 & 0 & 0 & 0 & 0 & 1 & 0 & 2 \\
\hline High school (other) & 2 & 0 & 3 & 2 & 7 & 3 & 3 & 20 \\
\hline High school in Tourism & 7 & 3 & 1 & 3 & 6 & 8 & 0 & 28 \\
\hline Bachelor degree (other) & 0 & 0 & 0 & 0 & 1 & 0 & 0 & 1 \\
\hline $\begin{array}{l}\text { Bachelor degree in } \\
\text { tourism }\end{array}$ & 3 & 2 & 1 & 0 & 4 & 3 & 0 & 13 \\
\hline Graduate (other) & 0 & 1 & 1 & 3 & 5 & 7 & 4 & 21 \\
\hline Graduate in Tourism & 11 & 8 & 3 & 5 & 23 & 21 & 4 & 75 \\
\hline Postgraduate (other) & 0 & 0 & 0 & 0 & 1 & 0 & 0 & 1 \\
\hline Postgraduate in Tourism & 1 & 0 & 0 & 0 & 0 & 1 & 0 & 2 \\
\hline Master (other) & 2 & 2 & 1 & 0 & 0 & 1 & 0 & 6 \\
\hline Master in Tourism & 2 & 0 & 0 & 0 & 0 & 2 & 0 & 4 \\
\hline $\mathrm{PhD}$ (other) & 0 & 0 & 0 & 0 & 0 & 0 & 0 & $\mathbf{0}$ \\
\hline $\mathrm{PhD}$ in Tourism & 0 & 0 & 0 & 0 & 0 & 0 & 0 & $\mathbf{0}$ \\
\hline Total & 29 & 16 & 10 & 13 & 47 & 47 & 11 & 173 \\
\hline
\end{tabular}

Source: Elaborated based on performed questionnaires to the travel agents

In this study, bivariate analysis was also performed using the Spearman correlation coefficient test, which allowed the analysis of the existence of correlations between the variables (Table 13). The first analysis was carried out with the variables "years as an agent" and "income" and the existence of a correlation between the two variables was verified, being this positive and moderate $(r=, 482)$. These results show that when a travel agent has more years of experience, he or she, also tends to have a higher income.

\section{Table 13: Correlation of Spearman}

\begin{tabular}{|l|c|}
\hline Variables & Correlation coefficient of Spearman \\
\hline Years as an agent &, 482 \\
Income & $\mathrm{p}<0,05$ \\
\hline Age & $\mathrm{p}<0,190$ \\
Education & $<05$ \\
\hline
\end{tabular}

Source: Elaborated based on performed questionnaires to the travel agents

In the second analysis carried out, with the variables "age" and "education", there is a negative and very low correlation between age and education $(R=-.190)$. Thus, it is possible to conclude that the older the agents are, the less educated they tend to be. 


\section{Conclusion}

This study provides important insights to characterize the human resources devoted to tourism in general, and in particular, in the sub-sector of travel agencies. Despite the existence of all the studies on human resources in tourism, there are not many studies on the travel agency sub-sector, which has proved to be the main limitation to this study. The various changes underway in the tourism sector have led companies to a greater demand for qualified human resources, many of them from higher education institutions (World Tourism Organization, 2020; Baum, 2015; Eurico, Silva \& Valle, 2012; Marques, 2019). These entail an enormous responsibility, as they must train future tourism professionals, with knowledge that will enable them to succeed in the working market.

The conclusions of this study are in line with the few previous investigations in the travel agents sub-sector. According to the results of the studies conducted by Portuguese Association of Travel Agencies and Tourism (APAVT, 2018) and Portuguese Tourism Board (Turismo de Portugal, 2017), professionals in this area have few educational qualifications, with the exception of the travel agency sub-sector, which is above average. From the results of this research, it was possible to confirm that most agents have higher education qualifications and specialization in this area, with the younger agents being the ones with the highest education qualifications. When income is mentioned, Portuguese Tourism Board (Turismo de Portugal, 2017) highlights that professionals in this area receive around 33\% less than other sectors of activity, meaning that they are poorly paid sectors. This statement is in line with the results found in this study, which confirm that the vast majority of travel agents receive between $501 €$ and $1000 €$, with the most experienced professionals being those with the highest incomes. In the view of Martins \& Machado (2002), low wages in this sector and a lot of working hours may be an obstacle to the recruitment of qualified human resources. As this is a low-paid area, they could be dissatisfied and want to leave this profession. However, the results of this study contradict this trend as about $73.2 \%$ are satisfied. The other agents, who want to leave the profession, cite poor pay and high levels of stress as the main reasons.

From the results obtained through the empirical component, it was possible to characterize the profile of the Portuguese travel agent in four elements: sociodemographical, economical, professional and psychological, which are possible to visualize in figure 2 .

\section{Figure 2: Travel agent profile in Portugal}

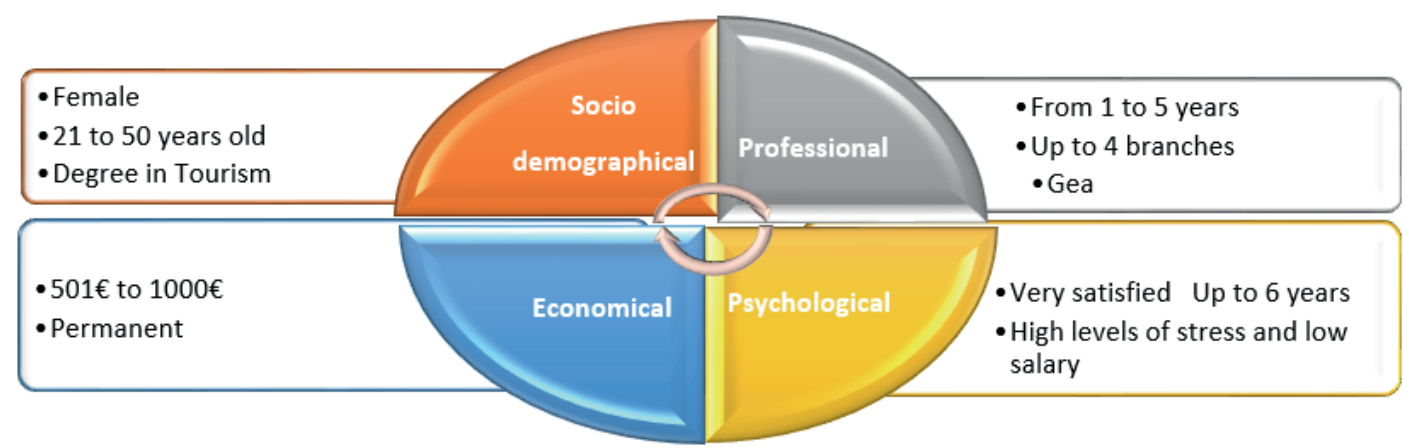

Source: Elaborated based on performed questionnaires to the travel agents

In short, this study made it possible to analyze the qualifications of travel agents and provide a signage profile of the professionals in this sub-sector of activity. Due also to a shortage of studies on this topic, future research focused on it would be pertinent: (i) motives why travel agents have higher education qualifications and receive very low salaries; (ii) investigation in greater detail the psychological profile of agents and understanding the levels of stress to which they are exposed and which often lead to them leaving the profession. 


\section{References}

Aamir, S., \& Atsan. N. 2020. The trend of multisided platforms (MSPs) in the travel industry: reintermediation of travel agencies (TAs) and global distribution systems (GDSs), Journal Tourism Future. DOI: https://doi.org/10.1108/JTF-10-2019-0121

Abranja, N.; Magalhães, C. 2018. Gestão de agências de viagens e turismo. 2. ${ }^{\text {a }}$ Edição. Lisboa: Lidel.

Associação Portuguesa de Agências de Viagens e Turismo 2018. O valor económico da distribuição em Portugal. Lisboa. APAVT.

Babu, S. 2014. Mass customerisation: next generation mass customisation for tourism. International Journal of Social Science and Management, 1: 115-119.

Baum, T. 2015. Human resources in tourism: Still waiting for change? - A 2015 reprise. Tourism Management, 50: 204-212. DOI: https://doi.org/10.1016/j.tourman.2007.04.005

Belleflamme, P., \& Neysen, N. 2009. Coopetition in Infomediation: General Analysis and Application to e-Tourism, Advances in Tourism Economics: New Developments pp. 217-234. DOI: https://doi. org/10.1007/978-3-7908-2124-6_14

Bestravel, 2020. Rede de agências. Obtained 18th August 2020, consulted at https://www.bestravel.pt/ info/agencias.aspx

B the Travel Brand, 2020. Agências de Viagens. Obtained 18th August 2020, consulted at https://www. bthetravelbrand.pt/agencias/

Buhalis, D. \& Kalis, K. 2008. eEnabled Internet Distribution for Small and Medium Sized Hotels: The Case of Athens. Tourism Recreation Research, 33: 67-81. DOI: https://doi.org/10.1080/02508281.11081291

Cetin, G., Cifci, M. A., Dincer, F. I., \& Fuchs, M. 2016. Coping with reintermediation: the case of SMHEs. Information Technology Tourism, 16(4): 375-392. DOI: https://doi.org/10.1007/s40558-016-0063-2

Cheung, R., \& Lam, P. 2009. How Travel Agency Survive in e-Business World? Innovation and Knowledge Management in Twin Track Economies Challenges and Solutions - Proceedings of the 11th International Business Information Management Association Conference, IBIMA 2009 1-3, pp. 900-907. DOI

Cooper, C. 2001. Turismo: princípios e práticas. Porto Alegre: Bookman.

Costa. C. 2006. Tourism Planning, Development and Territory In: Buhalis, D. Costa. C (eds.). Tourism Management Dynamics - Trends Management And Tools (pp.236-244). Oxford: Elsevier.

Costa. J. 2004. The Portuguese tourism sector: key challenges for human resources management. International Journal of Contemporary Hospitality Management, 16 (7): 402-407.

Costa. V., Moura. A., Mira. M., Cerdeiras. A., Cruz. I., Pereira. F., Martins. M., Conceição. O., Pinheiro, B., \& Almeida. C. 2019. Profile of Human Resources and Skills Needs in the Portuguese Tourism Sector. ECMLG 2019 15th European Conference on Management, Leadership and Governance. DOI: http://10.34190/MLG.19.111

DGES 2019. Quadro de Qualificações. Obtained 28th March 2019, consulted at https://www.dges.gov. $\mathrm{pt} / \mathrm{pt} /$ quadro_qualificacoes

Diário da Républica Eletrónico 2018. Decreto de lei nº 17/2018. Obtained 26th May 2019, consulted at https://dre.pt/application/conteudo/114832293

Eurico, S., Silva, J., Valle, O. 2012. Recursos Humanos Qualificados no Turismo: Factores de Diferenciação nos Polos de Desenvolvimento Turístico do Oeste e de Leiria-Fátima. Tourism and Management Studies, 8: 30-40

Forte, A. 2017. Turismo: Educar, Formar e Empregar. Lisboa: Turisver.

Geostar. 2020. Rede Geostar. Obtained 16th August 2020, consulted at https://www.geostar.pt/info/ rede-geostar

Granados, N., Kauffman, R., Lai, H., \& Lin, H. 2014. Decommoditization, Resonance Marketing, and Information Technology: An Empirical Study of Air Travel Services amid Channel Conflict. Journal of Management Information Systems, 28(2): 39-74. DOI: https://doi.org/10.2753/MIS0742-1222280203

Ibarnia, I. 2018. La sostenibilidad de la cadena de intermediacion turística. El caso de las agencias de viajes del pais Basco. Universitat Oberta Catalunya.

Kotler, P., Bowen, J., Makens, J. C., Moreno, R. R., \& Paz, M. D. R. 2003. Marketing para turismo. McGraw-Hill.

Kracht, J., \& Wang, Y. 2009. Examining the tourism distribution channel: Evolution and transformation. International Journal of Contemporary Hospitality Management, 22(5): 736-757. DOI: https://doi. org/10.1108/09596111011053837 
Lee, H., Guillet B. D., \& Law. R. 2013. An examination of the relationship between online travel agents and hotels a case study of choice hotels international and Expedia.com. Cornell Hospitality Quarterly Q, 54: 95-107. DOI: https://doi.org/10.1177/1938965512454218

Lillo-Bañuls, A., Sevilla, M., \& Ramón-Rodriguez, A. 2007. El capital humano como fator estratégico para la competitividad del setor turístico. Cuadernos de Turismo, 19: 47-69.

Lin, S. W. 2017. Identifying the critical success factors and an optimal Solution for Mobile Technology Adoption in Travel Agencies. International Journal of Tourism Research, 127-144. DOI: https://doi. org/10.1002/jtr.2092

Loaiza, J.,Pérez-Torres, A., \& Contreras, K. 2019. Semantic Icons: A Sentiment Analysis as a Contribution to Sustainable Tourism. Sustainability, 11(17): 46-55. DOI: https://doi.org/10.3390/su11174655

Marques, A. 2019. A importância da qualificação dos recursos humanos no Turismo: O caso dos hosteis da cidade do Porto. Escola Superior de Hotelaria e Turismo do Politécnico do Porto.

Martínez-Martínez, A., Cegarra-Navarro, J., \& Wensley, A. 2017. A long-term view of knowledge agents as key enablers of environmental knowledge. Proceedings of the European Conference on Knowledge Management, ECKM 2, pp. 632-633.

Martins, C., \& Machado., C. 2002. A importância dos recursos humanos no sector hoteleiro. Instituto Politécnico de Bragança.

Mckercher, B., Packer, T., Yau, M., \& Lam, P. 2003. Travel agents as facilitators or inhibitors of travel: perceptions of people with disabilities. Tourism Management, 24, pp. 465-474. Doi https://doi. org/10.1016/S0261-5177(02)00107-3

Mercados das Viagens 2020. A nossa rede. Obtained 18th August 2020, consulted at https://www. mercadodasviagens.pt/optitravel/www/layouts/mercadodasviagens/lojas.php

Mistilis, N., Buhalis, D. \& Gretzel, U. 2004. Future edestination marketing: perspective of na Austrian tourism stakeholder network. Journal of Travel Research, 53: 778-790. DOI. https://doi. org/10.1177/0047287514522874

Novak, J., \& Schwabe, G. 2009. Designing for reintermediation in the brick-and-mortar world: Towards the travel agency of the future, Electronic Markets, 19(1): 15-29. DOI: https://doi.org/10.1007/ s12525-009-0003-5

Pallas, A. 2018. Coexistence of the online and offline business in Spanish travel agencies as a result ok the changes introduced by the ICT and consumer buying habits. Espacios 39.

Pencarelli, T., Bravi, L., Dini, M., \& Splendiani, S. 2020. Enhancing customer experience through technological innovation in traditional travel agencies: evidences from Italy, Current Issues in Tourism. DOI: https://doi.org/10.1080/13683500.2020.1734548

Poon, A. 1993. Tourism, Technology and Competitive Strategies. New York, CAB International.

Ribeiro, L. 2019. Educação e formação profissional em Turismo na área da intermediação: Uma análise aos agentes de viagens portugueses. Maia: Instituto Universitario da Maia.

Sahut, J. M. 2009. The Impact of Internet on Pricing Strategies in the Tourism Industry. Journal of Internet Banking and Commerce, 14.

Salgado, A., Lemos, F., \& Rosa, M. 2016. A importância da Gestão Turística no Ensino Superior em Portugal. ResearchGate.

Silva. M. 2009. A Distribuição Turística e as Redes de Agências de Viagens em Portugal. Aveiro: Universidade de Aveiro.

Silva, M. 2017. Liderança estratégica do turismo em Portugal: Fatores moderadores. Aveiro: Universidade de Aveiro.

Sousa, F., \& Pereira, M. 2015. Agência Abreu - Uma viagem de 175 anos. Porto: Agência Abreu.

Top Atlântico. 2020. A nossa rede. Obtained 16th August 2020, consulted at https://www.topatlantico. pt/info/rede-top-atlantico

Turismo de Portugal. 2017. Estratégia Turismo 2027. Lisboa: Turismo de Portugal

Turismo de Portugal. 2018 a. Agência de Viagens e Turismo. Obtained 26th May 2019, consulted at http://business.turismodeportugal.pt/pt/Planear_Iniciar/Como_comecar/Agencias_Viagem_Turismo/ Paginas/default.aspx

Turismo de Portugal. 2018 b. Consulta ao registo agência de viagens e turismo. Obtained 16th November 2018, consulted at https://rnt.turismodeportugal.pt/RNAVT/ConsultaRegisto.aspx?

Turismo de Portugal. 2020. Visão Geral. Obtained 17th July 2020, consulted at http://www.turismodeportugal.pt/pt/Turismo_Portugal/visao_geral/Paginas/defau lt.aspx

Vallespín, M. \& Molinillo, S. 2014. El futuro de la intermediación en el sector turístico. Revista de Análisis Turístico, (17): 13-25. DOI: https://doi.org/10.1234/RAT2011n11 
Viagens El Corte Ingles. 2020. Agências. Obtained 16th August 2020, consulted at https://www. viagenselcorteingles.pt/agencias-viagens

Viljoen, K., \& Roberts-Lombard, M. 2016. Customer retention strategies for disintermediated travel agents: How to stop customers from migrating to online booking channels. Journal of Applied Business Research, 32: 681-694. DOI: https://doi.org/10.19030/jabr.v32i3.9669

Xiang, Z., Magnini, V., Fesenmaier, D. 2015. Information technology and consumer behaviour in travel and tourism: insights from travel planning using the internet. Journal of Retailing and Consumer Services, 22: 244-249. DOI: https://doi.org/10.1016/j.jretconser.2014.08.005

Wijk, J. V., Persoon, W. 2006. A Long-haul Destination: Sustainability Reporting Among Tour Operators; European Management Journal, 24(6): 381-395. DOI: https://doi.org/10.1016/j.emj.2006.07.001

World Tourism Organization. 2020. El futuro del trabalho en el turismo y el desarrollo de competências. 2020 Edition, Madrid: UNWTO. 